\title{
HULING HULING ACCA (HHA) AS ENGLISH RIDDLES FOR FUN EFL LEARNING STRATEGY IN TOBA Sadrakh Saprianto Hutabarat ${ }^{1}$, Syabillah Aura Shafitri, Mariana Tarigan Azizah Husda, S.S., M.Hum. ${ }^{4}$ \\ English Language Education, University of Prima Indonesia, Medan Indonesia Email: Sadrakh.sapriantohutabarat90@gmail.com
}

\begin{abstract}
In this study the researchers want to describe about Huling-huling Acca (Hha) As English RiddlesFor Fun EFL Learning Strategy In Toba. In conducting the researchers, the research designis Etnografi is a type of qualitative research design. To collect the data the study employ the interview with five questions and observation given to children and the people of Sosordolok, Toba Samosir. This study investigest of HHA as English riddles with five types of values according by (Paul Suparno), there are; sosialismy, adversity quotient, responsibilities, environment, self-relience. Asa result the study, It turns out that a lot of kids and people around here are poorly informed abouthuling-huling acca (hha). As researchers carried out further research, many people which had come to understand hha have proved invaluable. To illustrate "sae mangan ro siganjang obuk" so the values can can in this example of hha are moral and ethical. Because it should have finished eatingthe rest of the dirt must be eaten. Therefore these hha can be made into a fun learning medium and as an enhanced batak culture in its own language.
\end{abstract}

Key words: Huling-huling acca, english riddles, EFL, learning strategy 
e-ISSN: 2686-1526

\section{CHAPTER I \\ INTRODUCTION}

Huling-Huling Acca (HHA) is a puzzle game in English which, like riddles, is a question and answer activity where the teacher will give the question and the answerer will guess the answer. English riddles have always been associated with things that smelled of humor, mystery, humor, and education. In this study, researchers will enter English riddlesinto the realm of education which will certainly produce values and morals. Puzzle games are excellent as ESL / EFL Tools because they require students to practice various languageskills to find solutions in finding answers with their critical minds. English riddles can also improve students' vocabulary mastery. (Tessa Apriandari, 2019) Students can easily remember the vocabulary that has been taught and the majority of students have a positiveresponse to the use of puzzle techniques in increasing students' vocabulary. Besides, puzzles can develop and motivate students in learning English, especially vocabulary. On the other hand, Middleton states that the puzzle game requires two cycles to improve students' vocabulary mastery.

English riddles can be used as an EFL learning strategy to improve a child's English language skills. English riddles games or question and answer activities in written or oral form to solve a question. In English Riddles, researchers found similarities in the oral tradition of the Batak tribe. Oral tradition is a literary work from a culture that can be toldby a particular community and developed from generation to generation. Oral tradition is a variety of knowledge and customs passed down from generation to generation orally, including not only folk stories, myths, and legends but includes community cognitive systems, history, customary law, practice, and medication (Tiworo et al., 2019). There aremany kinds of oral traditions in society, such as Manulangi Tulang, mangongkal Holi, Umpasa, Turi-turian, Ende, Esek-esek, Mamoholi, and Huling-Huling Acca. In this study, the researcher found the similarity between English Riddles and the Batak Toba oral tradition, namely HHA. HHA is a hobo puzzle, which contains elements of humor, education, and certain values for learning as well as fun for children or students. HHA is appropriate to be applied to the younger generation as a learning medium to instill 
enthusiasm for learning and add social value to them because HHA is pragmatic oral literature. Pragmatics aims to improve human life and activities to meet human needs. Anexample of Huling Huling Acca "Sae Mangan ro siganjang obuk" If in English it mean is coming" in language, the meaning is "after eating a creature with long hair comes what is it?". Of course, the answer is a broom. Because a 'broom' is like a creature that has long hair like a devil. So the values contained in this example of HHA are moral and ethical. Because it should have finished eating the rest of the dirt must be cleaned. From that statement, the authors decided to formulate the problems of this research including what are the HHA values that can be obtained from EFL learners and how do you students respond to using HHA in the context of EFL.

Although HHA is classified as a game, HHA can hone a child's thinking skills so that when playing it will be faster in responding to something both from seeing, listening, and feeling. Usually, when using huling-hulingan there will be a questioner and answerer.When the asker asks a question, the person will say "hutissa" and the answerer will reply "Acca". This is when the question-and-answer activity takes place in a roundabout. It is known that the existence of the oral tradition of huling-huling Acca is undergoing modification (major changes) over time and can even be said to be almost extinct. Time does not rule out the extinction of this oral literature, both due to the influence of modernization and westernization. That's why this study aims to introduce HHA to the public or students who have almost forgotten it so that HHA can be maintained. As well aslearning English in the field of oral literature, so that it can get the values contained in the meaning of huling huling Acca and serve as a fun EFL learning strategy in Toba.

Based on the explanation above, the authors are interested in researching educationalbased Acca huling as the subject of this research to revive this oral tradition by the predetermined title "Huling-Huling Acca as English Riddles for Fun EFL LearningStrategy in Toba. 
e-ISSN: 2686-1526

\section{CHAPTER II}

\section{RESEARCH METHOD}

Based on the problems that have been determined, the researchers decided touse a qualitative descriptive method. This research is in the form of data in the form of words and natural explanations in the form of descriptive analysis.

Qualitative research is research that investigates, finds, describes, or describes, explains social privileges that cannot be explained, measured, or described through quantitative research (Emiliasari \& Fauzi, 2005). Then interpreted according to the objectives to be achieved. In qualitative research, data collection techniques using observational methods are needed. (Fajarini, 2017) state that one of the reasonsfor using the method of observation in qualitative research is to look directly at an object, observe certain phenomena during research, and record behavior and events according to the actual situation. Based on this explanation, qualitative research aims for a deep understanding of a problem formulation in a problem that will be studied and analyzed with a series of words along with descriptive explanations.

In this qualitative method, the writer uses an ethnographic approach. The Ethnographic approach is a study that focuses on analyzing behavior related to the culture of a society or social group or it can be said that the ethnographic approach is a social science or sociological research. (Puspitasari \& Kusumawijaya, 2020) states that ethnographic research is a sociological research that is carried out with closed observations of a culture. Meanwhile, Harris (Edition, 2014) states that ethnography is a study that observes the behavior and behavior, values, and beliefs of a culture or social group. Researchers deliberately used an ethnographic approach because this study was conducted to observe and observe the oral traditions of the population in the village of Sosordolok, Sianjur Mula Mula, Samosir, to obtain data that was in line with the researchers' expectations.

The data obtained in this study are derived from the HHA itself. Research data are all facts that have been collected from the object of research, namely HHA, whether in the form of numbers or letters. the research instrument used was the researcher himself, assisted by recording devices such as cameras and smartphones and using data 
recording tools such as observation forms and notebooks and pens as field notes. Breaking more about knowledge about hha, the researcher does interview techniques in data collection to obtain the results you want. The interview technique was performed with each child which was observed by giving understanding and introduction about hha, then continue to the q\&a process. From the results of the q\&a, the researchers draw conclusions from the results of the interview.

Obtained the data analysis technique stage in this study was obtained from the method of observation and interviews. Presenting data or compiling data according to predetermined problems and drawing conclusions from data analysis in the form of reports. Based on the explanation above according to the category, this study uses an interactive model by Miles and Huberman in analyzing the data from the results of this study. There are interactive modes from Miles and Huberman including, Data reduction, Data display and conclusion.

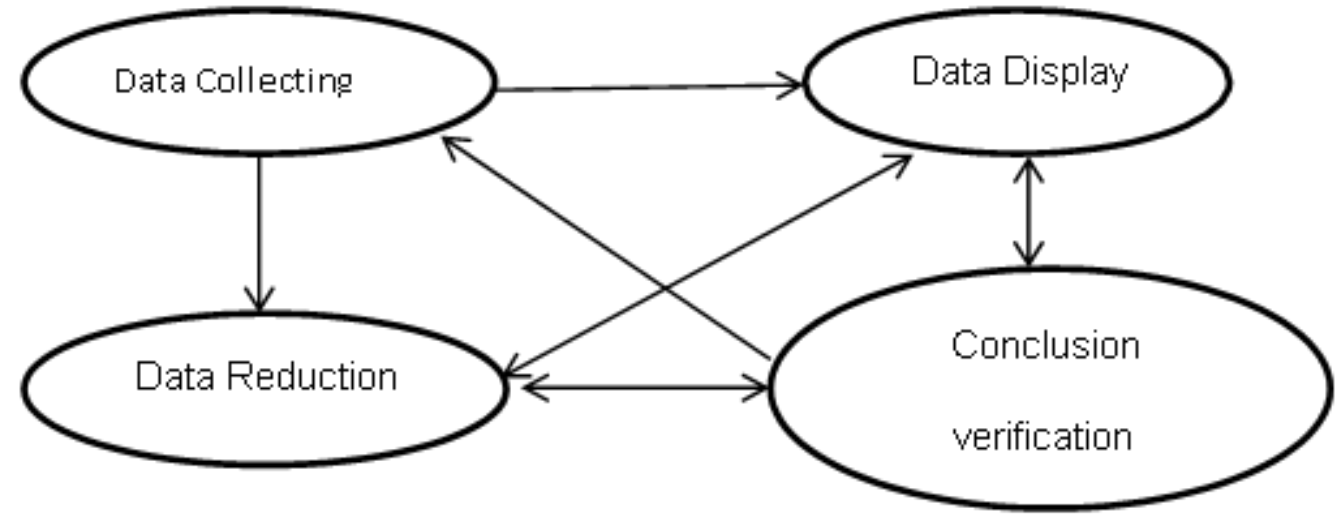




\section{CHAPTER III}

\section{DATA ANALYSIS, FINDINGS, AND DISCUSSIONS CHAPTER IV}

\subsection{The meanings of HHA for EFL of learning strategy}

\begin{tabular}{|c|c|c|c|c|c|}
\hline $\mathrm{NO}$ & HHA & TRANSLATION & ANSWER & MEAN & VALUE \\
\hline 1 & $\begin{array}{l}\text { Sae mangan ro } \\
\text { siganjang obuk }\end{array}$ & $\begin{array}{l}\text { After eating, came a } \\
\text { ghost with long hair }\end{array}$ & Broom & $\begin{array}{l}\text { After eating, you } \\
\text { should clean up } \\
\text { leftovers so that they } \\
\text { are neat }\end{array}$ & $\begin{array}{l}\text { Responsibility } \\
\text { value }\end{array}$ \\
\hline 2 & Ditallik dakka tipul & $\begin{array}{l}\text { It was cut many times } \\
\text { and didn't break either }\end{array}$ & Water & $\begin{array}{l}\text { Whatever obstacles } \\
\text { you face, no matter } \\
\text { how difficult it is, } \\
\text { stay strong and don't } \\
\text { get discouraged } \\
\text { easily }\end{array}$ & $\begin{array}{l}\text { Fighting } \\
\text { power value }\end{array}$ \\
\hline 3 & $\begin{array}{l}\text { Molo di jomur gabe } \\
\text { maraek }\end{array}$ & $\begin{array}{l}\text { If in the sun it } \\
\text { becomes wet/liquid }\end{array}$ & Ice cube & $\begin{array}{l}\text { Stay tough and } \\
\text { steadfast even in } \\
\text { your uncomfortable } \\
\text { zone. }\end{array}$ & Life value \\
\hline 4 & $\begin{array}{l}\text { Na jonok dang } \\
\text { hadungdungan, na } \\
\text { dao hadungdungan. }\end{array}$ & $\begin{array}{l}\text { What is near cannot be } \\
\text { reached, what is far } \\
\text { away can be reached. }\end{array}$ & Elbow & $\begin{array}{l}\text { Not all things can be } \\
\text { mastered by humans, } \\
\text { because humans } \\
\text { have limits }\end{array}$ & Moral value \\
\hline 5 & $\begin{array}{l}\text { Molo dibukka gabe } \\
\text { tukkot, molo di tutup } \\
\text { gabe tenda. }\end{array}$ & $\begin{array}{l}\text { If it is closed it can } \\
\text { become a stick, if it is } \\
\text { opened it can become } \\
\text { a tent. }\end{array}$ & Umbrella & $\begin{array}{l}\text { Be wise in using } \\
\text { yourself and your } \\
\text { life, to be useful }\end{array}$ & $\begin{array}{l}\text { Socialismy } \\
\text { value }\end{array}$ \\
\hline
\end{tabular}

\subsection{The Values Of HHA for Fun as Learning Strategy}

As for the moral value to be analyzed in this study is according to said that morality's (Suparno, 2012) there are; 1. The value of responibility, 2. The value of fighting power 3). The value of life, 4 . The Value of moral and 5. The value of socialismy

\subsubsection{The Value of Responsibilities}

Responsibility value, is explained that this hha is applied to students to maintain aesthetic and ttitude in the family when they are finished eating with the family so that it becomes a habit in shaping character in maintaining cleanliness and tidiness. 
e-ISSN: 2686-1526

\subsubsection{The Value of Fighting Power}

The value of fighting power explains that this is applied to students so that they do not easily never give up in facing challenges such as learning given by the teacher, both questions and materials that must be resolved. So that with the example of this HHA it can add to the spirit of enthusiasm and optimism of students.

\subsubsection{The Value of Life}

The value of life explains that this HHA is applied to students so that it is not like ice when it is dried in the sun it will melt. This HHA can be empowerment for students so that they remain tough and not easily give up in facing problems and are not easily influenced by a toxic environment.

\subsubsection{The Value of Moral}

The moral of value It was explained that the example from the HHA abovecould describe the meaning to students so that they are not easily arrogant about what they have from their abilities. Because no matter how strong and smart humans are, they must have certain weak points, meaning that not all can be reached easily because we have our own limitations 
e-ISSN: 2686-1526

\subsubsection{The Value of Socialism}

The socialismy value above teaches students to be individuals who can be useful to those around them. What is mult i-functional, such as an umbrella, if closed it can be used as a stick, while if it is opened it can become a tent or protection from rain or sun.

\subsection{Tabel the Aims of Using HHA as a fun EFL learning strategy}

\begin{tabular}{|c|l|c|l|}
\hline \multirow{2}{*}{ No. } & \multicolumn{1}{|c|}{ Question } & Observation & \multicolumn{1}{|c|}{ explanation } \\
\cline { 3 - 3 } 1 & $\begin{array}{l}\text { To foster and develop } \\
\text { an interest in learning }\end{array}$ & $\checkmark$ & $\begin{array}{l}\text { Because HHA uses the puzzle method in classroom } \\
\text { learning so that students are more active and cheerful and } \\
\text { encourage their interest in learning in participating in- } \\
\text { class learning. }\end{array}$ \\
\hline 2 & $\begin{array}{l}\text { To revitalize Toba } \\
\text { culture/language in } \\
\text { foreign language } \\
\text { learning }\end{array}$ & $\checkmark$ & $\begin{array}{l}\text { Because the HHA has been very forgotten and almost } \\
\text { lost in the Toba language culture, by using the HHA as a } \\
\text { teaching material students/teachers can reuse it in a } \\
\text { wider situation. }\end{array}$ \\
\hline 3 & $\begin{array}{l}\text { To break the academic } \\
\text { atmosphere }\end{array}$ & $\checkmark$ & $\begin{array}{l}\text { HHA can be used as a game that makes students more } \\
\text { active and livens up the learning atmosphere. }\end{array}$ \\
\hline 4 & $\begin{array}{l}\text { As a variety of } \\
\text { learning strategies }\end{array}$ & $\square$ & $\begin{array}{l}\text { To foster students' curiosity, investigate (participate) } \\
\text { in finding what HHA is. }\end{array}$ \\
\hline 5 & $\begin{array}{l}\text { Increase the kinship of } \\
\text { social interactions } \\
\text { between students and } \\
\text { teachers. }\end{array}$ & $\square$ & $\begin{array}{l}\text { Because with the HHA strategy, the atmosphere in the } \\
\text { classroom becomes more cheerful and active so that } \\
\text { students and teachers become more enthusiastic in the } \\
\text { teaching and learning process. }\end{array}$ \\
\hline 6 & $\begin{array}{l}\text { Upgrade } \\
\text { And hone in thinking }\end{array}$ & $\square$ & $\begin{array}{l}\text { Because the existence of HHA makes students' brains } \\
\text { more active in broad thinking (exploratory) to solve } \\
\text { HHA answers. }\end{array}$ \\
\hline
\end{tabular}


English Language Teaching Prima Journal, Vol. 2, No. 2. 2021

e-ISSN: 2686-1526

\begin{tabular}{|c|l|c|l|}
\hline \multirow{2}{*}{ Num. } & \multicolumn{1}{|c|}{ Question } & Observation & \multicolumn{1}{|c}{ Answer } \\
\cline { 2 - 3 } 1 & $\begin{array}{l}\text { How do you think } \\
\text { about the use of HHA } \\
\text { while studying } \\
\text { English? }\end{array}$ & $\checkmark$ & $\begin{array}{l}\text { The use of HHA when learning English is very good and } \\
\text { interesting because this HHA can increase children's } \\
\text { interest in thinking and make HHA and entertainment for } \\
\text { students during the learning process. }\end{array}$ \\
\hline 2 & $\begin{array}{l}\text { What can you get while } \\
\text { studying HHA in } \\
\text { English? }\end{array}$ & $\checkmark$ & $\begin{array}{l}\text { Obtaining the values and knowledge of a Batak culture } \\
\text { that have almost disappeared. }\end{array}$ \\
\hline 3 & $\begin{array}{l}\text { Can this HHA be } \\
\text { applied as a learning } \\
\text { method by teachers in } \\
\text { schools? Please explain } \\
\text { reason. }\end{array}$ & $\checkmark$ & $\begin{array}{l}\text { Yes, because it can make students more enthusiastic in } \\
\text { learning and make their thinking power more fluent. }\end{array}$ \\
\hline 4 & $\begin{array}{l}\text { Why does HHA need } \\
\text { to be studie as a } \\
\text { learning strategy? }\end{array}$ & $\checkmark$ & $\begin{array}{l}\text { Because of the HHA is a new strategy that is very rare and } \\
\text { rarely done in school. }\end{array}$ \\
\hline 5 & $\begin{array}{l}\text { What do you think if } \\
\text { English Riddles? }\end{array}$ & $\begin{array}{l}\text { Very good, because this HHA helps students in the } \\
\text { process of learning English to foster student curiosity and } \\
\text { reduce boredom during the learning and teaching process. }\end{array}$ \\
\hline
\end{tabular}




\section{CONCLUSION}

\subsection{Conclusion}

In the analysis of this research, it is concluded that it can provide some data in helping the student learning process. So that this HHA can develop widely and be known to many audiences. HHA is not a work/tradition of Batak, which is merely entertainment in the community, especially students and teachers, because it contains instrumental and valuable values worthy of being applied in education such as for teachers, namely, as teaching materials and learning strategies. And for students can obtain such moral values, there are the value of socialism, the value of adversity quotient, the value of responsibility, the value of appreciation for the environment, and the value of self-reliance contained in HHA, and to increase thinking ability and improve ability in the English language.

\subsection{Suggestion}

We suggest to the institution of education whose school is on Samosir Island to use HHA or the Tradition of Batak Toba as a school-building character. We suggest to the institution of education whose school is on Samosir Island to use HHA or the Tradition of Batak Toba as a school-building character. Some Suggestions that researchers are giving are as follows:

1) It is expected that the younger generation of Batak Toba to care more about the culture of oral traditions, such as HHA. Even though hha hasn't developed in years, we as a younger generation must continue to learn.

2) For the younger generation, Batak Toba, it is hoped to further examine the cultural meaning and values of hha by using different studies. To cultivate a love of culture and preserve it.

3) It is hoped that this studywill reference further studies, especially in language education studies. 


\section{REFERENCES}

Abiyoga, T. A., Sulistyo, E. T., \& Yulianto, N. (2018). SCROLL TECHNIQUE LEARNING IN MAKING OF CREATIVE WOOD PRODUCTS IN STUDENT CLASS XI KRIYA KAYU SMK NEGERI 9 SURAKARTA YEAR OF 2017 / 2018. 470-477.

Ardiana, Y. A. (2020). THE INFLUENCE OF STUDENTS' MOTIVATION AND ATTITUDES IN ENGLISH LEARNING TOWARD THEIR ENGLISH ACHIEVEMENT AT EDI MANCORO ISLAMIC BOARDING SCHOOL A Graduating Paper Submitted to the Board of Examiners as a Partial Fulfillment of the Requirements for the Ba.

Budiningsih, C. A. (2004). Perkembangan Moral. Jakarta: PT Asdi Mahasatya.

DEWI, R. P. (2019). Studi Kasus - Metode Penelitian Kualitatif. April 2015, 31-46. https://doi.org/10.31227/osf.io/f8vwb

Edition, T. (2014). Creswell - Research Design.

Emiliasari, R. N., \& Fauzi, E. M. (2005). Junior High School MGMP Majalengka for English Language Subject. 14, 158-163.

Fajarini, N. (2017). Pemanfaatan Perpustakaan Asmaina Terhadap Minat Baca Anak Pada Jenjang Pendidikan Dasar dan Menengah Dusun Plumbon Tengah, Mororejo, Tempel, Sleman. Uny, 58.

Hasanah, A., Gustini, N., \& Rohaniawati, D. (2016). Cultivating Character Education Based on Sundanese Culture Local Wisdom. Jurnal Pendidikan Islam, 2(2), 231. https://doi.org/10.15575/jpi.v2i2.788

Miles, M., Huberman, M., \& Saldaña, J. (2013). Qualitative Data Analysis: A Methods Sourcebook: An Expanded Sourcebook. 408.

Puspitasari, R., \& Kusumawijaya, A. (2020). Labor Informalization and Social Problems in Indonesia in Gender Equality Study (Case Study of Layoffs as the Effect of Digitalization in Cirebon City in 2019). Sunan Kalijaga: International Journal of Islamic Civilization, 3(1), 58. https://doi.org/10.14421/skijic.v3i1.1869

Rennie, L. (2007). Values of science portrayed in out-of-school Contexts (pp. 197-212). Brill | Sense. https://doi.org/https://doi.org/10.1163/9789087901677_017 
Song, L., Singleton, E. S., Hill, J. R., \& Koh, M. H. (2004). Improving online learning: Student perceptions of useful and challenging characteristics. Internet and Higher Education, 7(1), 59-70. https://doi.org/10.1016/j.iheduc.2003.11.003

Sudarti, N. W. (2013). Analisis Struktur dan Kaidah Kebahasaan Teks Cerita Ulang Biografi Karya Mahasiswa Program Studi Bimbingan Konseling IKIP PGRI Bali. Journal of Chemical Information and Modeling, 53(9), 1689-1699. https://doi.org/10.5281/zenodo.3517987

Suparno, P. (2012). Peran Pendidikan Dan Penelitian Terhadap. 1-11.

Tessa Apriandari. (2019). Improving Students' English Vocabulary through the use of Riddles Technique for the second years students at MTs Darul Ihsan Aceh Besar. 18-19.

Tiworo, K., Kabupaten, U., Barat, M., \& Hermina, S. (2019). RITUAL BANTANG PADA SUKU BAJO DI DESA TASIPI KECAMATAN TIWORO UTARA KABUPATEN MUNA BARAT Riski Hamriani. 2(2), 11-19.

Abiyoga, T. A., Sulistyo, E. T., \& Yulianto, N. (2018). SCROLL TECHNIQUE LEARNING IN MAKING OF CREATIVE WOOD PRODUCTS IN STUDENT CLASS XI KRIYA KAYU SMK NEGERI 9 SURAKARTA YEAR OF 2017 / 2018. 470-477.

Ardiana, Y. A. (2020). THE INFLUENCE OF STUDENTS' MOTIVATION AND ATTITUDES IN ENGLISH LEARNING TOWARD THEIR ENGLISH ACHIEVEMENT AT EDI MANCORO ISLAMIC BOARDING SCHOOL A Graduating Paper Submitted to the Board of Examiners as a Partial Fulfillment of the Requirements for the Ba.

Budiningsih, C. A. (2004). Perkembangan Moral. Jakarta: PT Asdi Mahasatya.

DEWI, R. P. (2019). Studi Kasus - Metode Penelitian Kualitatif. April 2015, 31-46. https://doi.org/10.31227/osf.io/f8vwb

Edition, T. (2014). Creswell - Research Design.

Emiliasari, R. N., \& Fauzi, E. M. (2005). Junior High School MGMP Majalengka for English Language Subject. 14, 158-163.

Fajarini, N. (2017). Pemanfaatan Perpustakaan Asmaina Terhadap Minat Baca Anak Pada Jenjang Pendidikan Dasar dan Menengah Dusun Plumbon Tengah, Mororejo, Tempel, Sleman. Uny, 58.

Hasanah, A., Gustini, N., \& Rohaniawati, D. (2016). Cultivating Character Education Based on 
Sundanese Culture Local Wisdom. Jurnal Pendidikan Islam, 2(2), 231. https://doi.org/10.15575/jpi.v2i2.788

Miles, M., Huberman, M., \& Saldaña, J. (2013). Qualitative Data Analysis: A Methods Sourcebook: An Expanded Sourcebook. 408.

Puspitasari, R., \& Kusumawijaya, A. (2020). Labor Informalization and Social Problems in Indonesia in Gender Equality Study (Case Study of Layoffs as the Effect of Digitalization in Cirebon City in 2019). Sunan Kalijaga: International Journal of Islamic Civilization, 3(1), 58. https://doi.org/10.14421/skijic.v3i1.1869

Rennie, L. (2007). Values of science portrayed in out-of-school Contexts (pp. 197-212). Brill | Sense. https://doi.org/https://doi.org/10.1163/9789087901677_017

Song, L., Singleton, E. S., Hill, J. R., \& Koh, M. H. (2004). Improving online learning: Student perceptions of useful and challenging characteristics. Internet and Higher Education, 7(1), 59-70. https://doi.org/10.1016/j.iheduc.2003.11.003

Sudarti, N. W. (2013). Analisis Struktur dan Kaidah Kebahasaan Teks Cerita Ulang Biografi Karya Mahasiswa Program Studi Bimbingan Konseling IKIP PGRI Bali. Journal of Chemical Information and Modeling, 53(9), 1689-1699. https://doi.org/10.5281/zenodo.3517987

Suparno, P. (2012). Peran Pendidikan Dan Penelitian Terhadap. 1-11.

Tessa Apriandari. (2019). Improving Students' English Vocabulary through the use of Riddles Technique for the second years students at MTs Darul Ihsan Aceh Besar. 18-19.

Tiworo, K., Kabupaten, U., Barat, M., \& Hermina, S. (2019). RITUAL BANTANG PADA SUKU BAJO DI DESA TASIPI KECAMATAN TIWORO UTARA KABUPATEN MUNA BARAT Riski Hamriani. 2(2), 11-19. 